\title{
THE CONCEPT OF ENEMY COMBATANT BY UNITED STATES: DOES INTERNATIONAL HUMANITARIAN LAW RECOGNIZED THIS CONCEPT? (CASE STUDY: ARMED CONFLICT BETWEEN UNITED STATES, AL QAEDA AND THE TALIBAN)
}

\author{
Adhitya Nini Rizki Apriliana \\ Master of Law, Universitas Airlangga \\ email : adhityaninirizki@gmail.com

\section{Lina Hastuti} \\ Universitas Airlangga \\ email : lina.hastuti@fh.unair.ac.id
}

\begin{abstract}
International humanitarian law recognized the classification of population during the war, namely: combatant; hors de combat; non-combatant; and civilians. Civilians is the parties who should be protected from enemy attacks and conversely this classification should not be attacked under any circumstances. In the other side of these classifications, the United States arrested around 200 Afghan children and teenagers on charges of being enemy combatant and detained them at the Detention Facility in Parwan. The act taken by the United States is not recognized in international humanitarian law since terms enemy combatant is not suitable with any other terms in international humanitarian law. The United States arrested children who did not took up arms and were not involved in the war but 'allegedly' involved with terrorist networks and were considered to treated state security. Phrase 'allegedly' refers to subjectivity and hard to describe. This research will discuss how international humanitarian law deal with the United States new terms namely enemy combatant. This study uses statutory approach which examining the laws and regulations concerned with the formulation of the problem discussed. It also uses conceptual approach which moves from the views and doctrines that develop in law to build a legal concept. This study is purpose to analyze legal basis and principles of international customary law related to the concept of enemy combatant as applied unilaterally by the United States to the armed conflict in Afghanistan.
\end{abstract}

Keywords: enemy combatant, armed conflict, international humanitarian law

\section{INTRODUCTION}

In the development of the history of human life there are many ways were known to resolve a conflict. One of them is by using the most traditional way, namely, by means of war. Begins from the expression 'peace to be merely a respite between wars', it can be said that the most recorded phenomenon being the main topics in the interaction of human life ranged between two things, war and peace. ${ }^{1}$ This is because basically human nature is proud to compete, so war is used as an option to conquer opponents.

\footnotetext{
${ }^{1}$ Ambarwati, Denny Ramdhany, Risa Rusman, Hukum Humaniter Internasional dalam Studi Hubungan Internasional, RajaGrafindo Persada, Jakarta, 2012, p. 2.
} 
Starts from the international community's awareness of the effects that can be caused by war, international humanitarian law was born as a balancing effort between military needs and the need to respect human nature. ${ }^{2}$ It is referred to as respect for the nature of human beings because international humanitarian law is not a regulation that regulates the procedures for contributing during a war but rather the rules that are created based on humanitarian reasons to reduce or limit the suffering of each individual involved. ${ }^{3}$ International humanitarian law is a sub-chapter of international law that contains a discussion of legal principles and norms that regulate actions that are prohibited and justified in war. ${ }^{4}$

In its discussion, international humanitarian law or currently known as international humanitarian law applicable in armed conflict, not only regulates the warring parties but also expands its discussion towards arrangements relating to interests civilians and the environment. ${ }^{5}$ This is because the international humanitarian law according to the ICRC contains international rules formed by international agreements or habits that are specifically expected to overcome the humanitarian problems that arise from international and non-international armed disputes and are based on humanity expected to be able to protect human rights the parties to the conflict as well as people who are possible to be affected by it. ${ }^{6}$

Human consciousness of the losses experienced during war changes many things. One of them is the aim of international humanitarian law which refers more to the emphasis on humanity, not just a discussion of the tools and methods of warfare. ${ }^{7}$ However, even though international humanitarian law has regulated in such a way, the impact caused by war remains significant. Misery, loss and suffering experienced by the people of the warring parties. It surely raises awareness of the international community to then begin to an effort to abolish war or at least reduce the impact caused by war. ${ }^{8}$ In its history, none of the wars left no casualties or material losses, moreover if the war was carried out continuously for even more than a decade. Just like the war between the United States and Afghanistan. The war, which lasted more or less for 16 years, was the second highest inflation war after World War II, which had a very significant impact on the Afghanistan economy. Although the United States is a superpower, they also feel the financial impact of the war since most of American family should prepare the treatment for their family whose contribute to the war in the Middle East. ${ }^{9}$

International humanitarian law recognizes the classification of parties during the war, namely: combatant; hors de combat; non-combatant; and civilians. Civilians is the parties who should be protected from enemy attacks and conversely this classification should not be attacked under any circumstances. This protection must be given to

\footnotetext{
${ }^{2}$ M. Iqbal Asnawi, "Konsistensi Penegakan Hukum Humaniter Internasional dalam Hubungan Antar Bangsa", Jurnal Hukum Samudra Keadilan, Volume 12, Nomor 1, Januari-Juni 2017, https://media.neliti.com/media/publications/240386-konsistensi-penegakan-hukum-humaniter-in-bf9e1eca.pdf, p. 112, accesed on May 10, 2019, quoted from Umesh Kadam, "Political and Social Science and International Humanitarian Law", Makalah, presented on International Humanitarian Seminar, Gajah Mada University, July 11-12, 2006, p. 1.

${ }^{3}$ Mery Enjelica Stephany Gumenggilung, "Pertanggungjawaban Atas Kerusakan Lingkungan Hidup Akibat Perang Berdasarkan Perspektif Hukum Humaniter Internasional”, Skripsi, Faculty of Law Kristen Satya Wacana University, Salatiga, 2016, p. 4 quoted from J. G. Starke, Pengantar Hukum Internasional Edisi Kesepuluh II (Terjemahan oleh Bambang Iriana Djajaatmadja, S.H.), Sinar Grafika, Jakarta, 1998, p. 728.

${ }^{4}$ Ibid, p. 14.

${ }^{5}$ Ambarwati, Denny Ramdhany, Risa Rusman, Op.Cit, p. 29.

${ }^{6}$ Ibid, quoted from ICRC, Commentary on the Additional Protocols of 18 June 1977, Martinus Nijhoff Publishers, Geneva, 1987, p. 27.

${ }^{7}$ Ibid.

${ }^{8}$ Ibid, p. 527.

${ }^{9}$ Nindiya Ayu Izarina, "Dampak Perang Afghanistan dan Timeline Perang Afghanistan", www.hukamnas.com, Januari 31, 2018, accesed on April 5, 2019.
} 
children as well. In a state of war, the Geneva Convention IV, especially in Article 24, clearly regulates the protection of civilians so that they are not involved in any kind of war. However, these terms are very difficult to practice. War conditions are conditions in which the parties cannot judge, which conditions are prohibited or vice versa, as stipulated in international humanitarian law. In the case of war, the parties will only take the strategy to conquer the enemy into account. Likewise, the case happened when the United States arrested around 200 Afghan children and teenagers on charges of being enemy combatant and detained them at the Detention Facility in Parwan. ${ }^{10}$

The arrest of Afghan children and teenagers by the United States certainly raises pros and cons, especially if it is associated with arrangements in international humanitarian law. For the arrests they made, the United States argued that this was done to save the psychology of Afghan children and teenager from an environment of conflict so it could prevent the generation who continued those terrorist act. This is done by the United States to stop the war keep continues in Afghanistan. But on the other hand, this arrest is also not justified considering that children and teenager arrested by the United States are not taking up arms or involved in warfare.

Based on the background described above, there are two issues can be drawn to discuss, namely: The position of the United States action in capturing Afghan children and teenagers as enemy combatant in International Humanitarian Law and Forms of protection provided by international humanitarian law to Afghan children and teenager arrested on charges as enemy combatant.

This study uses statutory approach and conceptual approach. The statutory approach is carried out by examining the laws and regulations concerned with the formulation of the problem discussed. ${ }^{11}$ While conceptual approach moves from the views and doctrines that develop in law to build a legal concept. This study is purpose to analyze legal basis and principles of international customary law related to the concept of enemy combatant as applied unilaterally by the United States to the armed conflict in Afghanistan.

\section{DISCUSSION}

\section{Chronology}

In 1999, the United Nations Security Council issued Resolution $1267^{12}$ and then formed a committee tasked with providing sanctions against Al Qaeda and the Taliban, the groups which were suspected of being terrorist entities. The issuance of Resolution 1267 by the United Nations Security Council was related to the arrest of the Iranian Consulate General by the Taliban, the murder of an Iranian Diplomat and a journalist, also the bombing of the US embassy in Nairobi and the condition where Osama bin Laden involves to this war with his colleagues. On September 9, 2001, Ahmad Shah Massoud ${ }^{13}$ was killed by Al-Qaeda. Al Qaeda also hijacked four commercial aircraft and crashed them into the World Trade Center in New York and the Pentagon in Washington. The

${ }^{10}$ Nickita Herzegovina Sumantri, "Penangkapan Anak-Anak dalam Konflik Bersenjata di Afghanistan dengan Tuduhan sebagai Enemy Combatant”, Skripsi, Faculty of Law Brawijaya University, Malang, 2013, p. 4.

${ }^{11}$ Peter Mahmud Marzuki, Penelitian Hukum, Prenada Media Group, Jakarta, p.133.

${ }^{12}$ UNSC Resolution No. 1267 was issued on October 15, 1999 in response to security conditions in Afghanistan which were considered to threaten international peace and security. Through this resolution, the United Nations asked the Taliban not to provide protection against terrorists and organizations related to terrorism. Through this resolution the United Nations also asked the Taliban to immediately hand over Osama bin Laden to the authorities to be tried in court.

${ }^{13}$ Ahmad Shah Massoud known as "Lion of Panjsher" since his brave to be a remembering his courage for became the Commander of the Northern Alliance which is an Anti-Taliban coalition, Abdulla Qazi, "Biography of Ahmad Shah Massoud" www.afghan-web.com, November 18, 2008, accesed on April 5, 2019. 
fourth plane crashed in a field in Shanksville, Pennsylvania. There were nearly three thousand people killed in the attack.

Even though Afghanistan is the base for al-Qaeda, none of the 19 hijackers involved in the hijacking of the commercial aircraft are Afghan citizens. Muhammad Atta, the leader of the piracy group from Egypt and 15 other hijackers from Saudi Arabia. ${ }^{14}$ In September 2001, President George W Bush signed a joint resolution which could become the basis for the Bush administration regarding the decision to take the next steps in fighting terrorism in Afghanistan. Then in October 2001, the United States Military with British support, began bombing the Taliban and officially launched Operation Enduring Freedom. ${ }^{15}$ Then in 2003, the Bush administration announced that a major war was over and NATO had a major role in stopping the war. This peaceful action continued until May 2005, Afghanistan's elected president, Hamid Karzai and US President George W. Bush signed an agreement allowing the US military to access Afghan military facilities. ${ }^{16}$

At the NATO Summit in Riga, Latvia, conflict started to emerge among member countries that were in coalition to fight terrorism in Afghanistan regarding the commitment of troops to Afghanistan. NATO Secretary General Jaap de Hoop Scheffer set a target for 2008 for the Afghan National Army to begin controlling the security of his own country. Jaap de Hoop Scheffer said at the conference that NATO hoped that in 2008, with a more stable political conditions in Afghanistan and effective coordination between NATO and civil institutions in Afghanistan, Afghan security forces could be trusted to gradually take control. ${ }^{17}$

Then in May 2007, a joint operation between NATO, US forces and Afghan forces succeeded in killing the Taliban military commander, Mullah Dadullah. In 2008, the United States accidentally killed Afghan civilians in an attack targeting the Taliban military. Based on the results of investigations carried out by Afghanistan and the United Nations, it was found that US combat ships actually killed around 27 Afghan civilians in the Shindand District. ${ }^{18}$ This situation was later exploited by the Taliban to denounce President Hamid Karzai and strengthen their claims regarding the inability of coalition forces to protect civilians.

The election of Barrack Obama as President of the United States in 2009 greatly changed the tactics and methods of war in Afghanistan, one of which was to replace Gen. McChrystal with Gen. David Petraeus as head of the United States military command in Afghanistan in 2010 and in 2011 killed the main target of the United States responsible for Al Qaeda, Osama bin Laden. Departing from the assassination of Osama bin Laden, various debates began to emerge in the midst of Afghan society so that the existence of the United States in Afghanistan began to be welcomed. The Taliban cancel the peace agreement between the Taliban and the United States. Furthermore, the United States made a massive withdrawal of its forces in Afghanistan and left only 9800 forces at the end of 2014.

Problems reappeared after Donald J. Trump was elected as a President of the United States in 2017. The United States dropped its most powerful non-nuclear bomb on Islamic State Militants in a cave complex in East Nangarhar Province. As the new president, Donald J. Trump stated that he would impose a new strategy that was different from

\footnotetext{
${ }^{14}$ Council on Foreign Relations, "The US War in Afghanistan", www.cfr.org, accesed on April 10, 2019.

${ }^{15}$ Operation Enduring Freedom is the term used by The United States to fight terrorism.

${ }^{16}$ Nindiya Ayu Izarina, Loc.Cit.

${ }^{17}$ Council on Foreign Relations, Loc.Cit.

${ }^{18}$ Detik News, "Hendak ke Pesta, 27 Warga Afghan Tewas Digempur AS", www.news.detik.com, July 7, 2008, accesed on April 25, 2019.
} 
what had been implemented by Barrack Obama. In addition, he also gave a signal that the war would be extended.

\section{The term 'Enemy Combatant' in International Humanitarian Law}

The war in Afghanistan in the perspective of international humanitarian law belongs to the category of internal armed conflict. Basically, the difference between international armed conflict and non-international armed conflict according to international humanitarian law lies in the nature and number of countries that are parties to the armed conflict. International armed conflict refers to the armed conflicts that involve countries as parties to the conflict. Whereas non-international armed conflict is an armed conflict involving the state with an armed group rather than the state as the party to the conflict. In this case, I Wayan Titib Sulaksana ${ }^{19}$ said that the war that occurred in Afghanistan was an internal armed conflict. It is not included in both international and non-international armed conflicts since this war was initially a war that occurred between the United States and an entity suspected of having terrorism namely Al Qaeda and the Taliban, not Afghanistan.

Refers to the chronology described, it can be seen that in 2001 there were hijacking to four commercial aircraft which were those commercial aircraft finally crashed into the World Trade Centre in New York and the Pentagon in Washington. It was became the point of factoring in the onset of war between the United States and the Al Qaeda and Taliban groups based in Afghanistan. In carrying out its retaliatory attacks, United States applies a term that is not yet known in international humanitarian law, namely enemy combatant. The term enemy combatant is a term developed by the United States to classify everyone who is considered to have involvement with Al Qaeda and Taliban groups. Basically, this term is not only used for Afghans or even specifically for A1 Qaeda and Taliban groups but is also used for everyone who is considered to have involvement with a terrorist network including United States citizens themselves can also be categorized as enemy combatant. ${ }^{20}$ International humanitarian law in this case does not recognize the term enemy combatant used by United States since this term is a term that has only been used by them according to the war against Al Qaeda and Taliban groups. International humanitarian law also has no regulation that explains which parties can be categorized as enemy combatant, whether enemy combatant are classified as civilians or civilians who take up arms, children and so on.

In that revenge operation, the United States arrested children who did not took up arms and were not involved in the war but 'allegedly' had involvement with terrorist networks and were considered to threaten state security. The arrests were carried out to save the young generation in Afghanistan from falling into radical ideology and continue to develop terrorist networks. Referring to the case when it is associated with the term enemy combatant, it can be stated that combatant enemies in international humanitarian law are located like unlawful combatant. The difference lies in the participation of children and teenagers arrested in the war. If in unlawful combatant civilians caught by opponents are parties who intervene in warfare, while in the enemy combatant, civilians caught by the opposing parties are purely civilians who did not have any participation in the warfare. ${ }^{21}$ By this act, the United States stated that the arrests

\footnotetext{
${ }^{19}$ International Humanitarian Law Lecturer in Universitas Airlangga, Surabaya.

${ }^{20}$ The American Bar Association, "Enemy Combatant", www.americanbar.org, accesed on April 30, 2019.

${ }^{21}$ Unlawful combatant in International Humanitarian Law are not explained in detail but the term is used for civilians who do not have the right to participate in warfare (so that if they are caught they cannot be protected or given prisoner-of-war status) but give interference in war, Nickita Herzegovina Sumantri, Op.Cit., p. 8.
} 
of Afghanistan civilians as enemy combatant prevented combatant from returning to the battlefield and continued fighting. It was also stated, that the law of war allowed the United States to arrest the warring parties until the fighting that had taken place was completed without prosecuting them with a crime, because basically they were not arrested and subsequently faced with the trial. ${ }^{22}$

United States on its act using enemy combatant as a legal term within the humanitarian law believes that the humanitarian law permits the United States to arrest the warring parties. In this case United States refers to the provisions of Article 5 Geneva Convention IV which state that "... the individual is definitely suspected of or engaged in hostile to the security of the State ... ". However, it should be noted that Article 5 Geneva Convention IV refers to the notion of unlawful combatant, namely aimed at civilians who have 'a direct contribution to warfare'. However, in Article 5 Geneva Convention IV there is a phrase "... definitely suspected ..." which seems to be used as a reference by the United States to arrest civilians who do not take up arms or even engage in warfare but are only suspected of endangering state security.

If we point to the Geneva Convention IV Commentaries, the phrase "... definitely suspected ..." comes from French, namely duneune suspicion légitime, which converted into English as: the suspicion must be a definite one. This means that in determining someone belongs to the category of endangering the security of the state so that it is justified to be arrested, the arresting party should have a strong reason that there is a definite involvement of the suspect person. Set out from this explanation, the problem is how the party that made the arrest, in this case the United States, has a serious reason to prove that the arrested person belongs to the category of enemy combatant.

Besides refers to Article 5 Geneva Convention IV, the United States also refers to Article 27 Geneva Convention IV which reads, "protected persons are entitled, in all circumstances, to respect for their persons, their honor, their family rights, their religious convictions and practices, and their manners and customs. They shall at all times be humanely treated, and shall be protected especially against all acts of violence or threats thereof and against insults and public curiosity...". Referring to the substance of Article 27 Geneva Convention IV, it can be seen that the United States in this case interpreted Article 27 Geneva Convention IV through a different perspective. According to the United States, “... protected person ..." in the Article must be protected in any way even by taking steps to caught these people so that they are saved from situations that can change their mindset into a radical mindset that leads to the acts of terrorism. Under their policy to applied term called enemy combatant, the United States did not arrest the Afghan children and teenagers to be detained as guilty people or belong to any punishment. They provided a precautionary measure so that the children and teenagers were not affected by the developing terrorist network in their country.

Although the United States believes that the arrests of Afghan children and teenagers is based on the status of enemy combatant, the United States is not allowed to treat Afghan children and teenagers as if they were unlawful combatant. It is simply because these two terms have significant differences. Unlawful combatant cannot be given 'prisoner-of-war' status because the parties included in the unlawful combatant classification are 'civilians who take up arms'. In this context, enemy combatant do not have any involvement on the ongoing war. Based on Geneva Convention, there

${ }^{22}$ Ibid, h. 9, quoted from Jim Lurie dan Torill Tjelflaat, 'Children's Rights and the UN Convention on the Rights of the Childs: Monitoring and Implementation in Norway', Dialogue in Praxis Social Work International Journal, Volume 1 (14), Issue 1-2 (22-23), 2012, p. 43. 
were several protection that should be provided by the United States to Afghan children and teenagers who were arrested. In accordance with Article 3 Geneva Convention IV, children must be treated humanely as civilians and must be given special treatment because they must be protected as civilians should be. In addition, according to Article 37 the International Convention on the Right of the Child ${ }^{23}$, these children and teenagers also have the right to be protected and may not be treated like adult detainees or even war opponents especially considering the arrests made by the United States are not justified by international humanitarian law. ${ }^{24}$

Especially for those children, Article 24 Geneva Convention IV guarantees that the warring parties will take 'necessary measures' for children under fifteen, orphans which separated from their families due to war so they would not left alone. These children will receive protection, nurture and assistance in the implementation of worship and education. $^{25}$

Facing Afghan children and teenagers detained by the United States, the International Committee of the Red Cross (ICRC) delegation visited the children and teenagers, provides them assistance to facilitate the children and teenagers to stay in touch with their families. The United States as the party that alleged the combatant enemy also worked cooperatively and did not prevent the ICRC or The Afghanistan Independent Human Rights Commission from visiting children and teenagers who were arrested. ${ }^{26}$

However, the arrests of Afghan children and teenagers committed by the United States remains unjustified in International Humanitarian Law, given that there is no strong legal basis that can be used as a basis for the arrest. In addition, the reasons used by the United States in conducting arrests also refer more to subjectivity because there is no reason and sufficiently strong evidence that these children and teenagers are involved in terrorist networks that endanger the state. Underage children especially those who do not take up arms are basically classified as civilians who must be protected and may not be involved in any armed conflict.

By using the term enemy combatant and making unilateral arrests of Afghan children and teenagers, the United States should have been subject to international sanctions. Before refers to the sanctions, it needs to be identified deeper that the United States is not only arresting Afghan children and teenagers then labeling them in terms that are not regulated in international humanitarian law. If tested further, the United States in this case also intervenes in the jurisdiction of other countries, in this case Afghanistan. Departing from the disruption of the recapitulation of Afghan sovereignty, the United States refers to this matter and has intervened too deep to Afghanistan's domestic affairs. International law recognizes the principles which reads as "par in parem non habet imperium", which means that the parties (countries) that have equal position do not have jurisdiction over other parties (equals do not have jurisdiction over each other). Speaking of sanctions that must be imposed on the United States, this would be very difficult since United States is a superpower and very dominant in this case. Refers to this condition, the United States condemned the International Criminal Court

${ }^{23}$ No one is allowed to punish children in a cruel or harmful way. Children who break the law should not be treated cruelly. They should not be put in prison with adults, should be able to keep in contact with their families, and should not be sentenced to death or life imprisonment without possibility of release, UNICEF, "A Summary of The Rights Under The Convention on The Rights of The Child", www.unicef.org, accesed on April 30, 2019, p. 3.

${ }^{24}$ Nickita Herzegovina Sumantri, Op.Cit., p. 16.

${ }^{25}$ Faisal Riza, "Perlindungan Anak yang Ditangkap oleh Militer Asing di Negara Konflik", De Lega Lata, Vol. I, No. 2, July- December 2016, https://media.neliti.com/media/publications/176706-ID-perlindungan-anak-yang-ditangkap-oleh-mi.pdf, p. 88, accesed on May 9, 2019.

${ }^{26}$ Nickita Herzegovina Sumantri, Op.Cit, p. 14. 
(ICC) because the ICC had investigated alleged war crimes by American military and intelligence personnel in Afghanistan. Moreover, the United States in its objection stated firmly that the ICC should not unilaterally investigate other parties who are not bound by a series of international humanitarian law regulations through the ratification process. Therefore, to deal with these problems the Afghanistan side can file a lawsuit through the ICC and request assistance from the United Nations to resolve internal armed conflicts between the United States and armed groups of the Taliban and Al Qaeda. According to information that has been summarized through several media, the United Nations is helping Afghanistan to release the Taliban from the blacklist so this can help the reconstruction process of Afghanistan. In addition, United States also conduct the mediation towards Al Qaeda and the Taliban so that the prolonged conflict will soon be over.

\section{CONCLUSION}

The arrest of children and teenagers who did not involve in the war in Afghanistan by the United States is not justified by international humanitarian law, especially Geneva Convention, since the term of enemy combatant is unknown by international humanitarian law. An enemy combatant has no similar specification with unlawful combatant like described in Article 5 Geneva Convention IV. It can be concluded that the United States cannot replace the term unlawful combatant by the term enemy combatant. There is no strong legal basis that can be used as a basis for the arrest. In addition, the reasons used by the United States in conducting arrests also refer more to subjectivity because there is no reason and sufficiently strong evidence that those children and teenagers are involved in terrorist networks that endanger the state. In this case, underage children especially those who do not take up arms are basically classified as civilians who must be protected and may not be involved in any armed conflict. By using the term enemy combatant and making unilateral arrests of Afghan children and teenagers, the United States should have been subject to international sanctions.

\section{BIBLIOGRAPHY}

\section{Books}

Hector Mac Queen, Charlotte Waelde \& Graeme Laurie, (2008), Contemporary Intellectual Property Law and Policy, Oxford University Press, New York

Ambarwati, (2012), Hukum Humaniter Internasional dalam Studi Hubungan Internasional. RajaGrafindo Persada, Jakarta.

Mochtar Kusumaatmadja, (1979), Konvensi-Konvensi Palang Merah tahun 1949 Mengenai Perlindungan Korban Perang, Penerbit Binacipta, Bandung.

Arlina Permanasari, (1999), Pengantar Hukum Humaniter, ICRC, Jakarta.

ICRC, (1987), Commentary on the Additional Protocols of 18June 1977, Martinus Nijhoff Publishers, Geneva.

J.G. Starke, (2008), Pengantar Hukum Internasional 2, Sinar Grafika, Jakarta.

D. Nigel White, (2014), International Conflict and Security Law, Edward Elgar Publishing, Massachusetts.

\section{Journals and Theses}

Riza, Faisal, (2016), Perlindungan Anak yang Ditangkap oleh Militer Asing di Negara

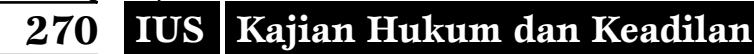


Konflik, De Lega Lata, July- December, Vol. I, No. 2.

Jim Lurie dan Torill Tjelflaat, Children's Rights and the UN Convention on the Rights of the Childs: Monitoring and Implementation in Norway, Dialogue in Praxis Social Work International Journal, 2012, Vol. 1 (14), Issue 1-2 (22-23).

Asnawi, M. Iqbal, (2017), Konsistensi Penegakan Hukum Humaniter Internasional dalam Hubungan Antar Bangsa, Jurnal Hukum Samudra Keadilan, January-June, Vol. 12, No. 1.

Sulistia, Teguh, Pengaturan Perang dan Konflik Bersenjata dalam Hukum Humaniter Internasional, Indonesian Journal of International Law, April 2007, Vol. 4, No. 3

Mery Enjelica Stephany Gumenggilung, "Pertanggungjawaban Atas Kerusakan Lingkungan Hidup Akibat Perang Berdasarkan Perspektif Hukum Humaniter Internasional", Theses, Fakultas Hukum Universitas Kristen Satya Wacana, Salatiga, 2016.

Nickita Herzegovina Sumantri, "Penangkapan Anak-Anak dalam Konflik Bersenjata di Afghanistan dengan Tuduhan sebagai Enemy Combatant", Theses, Fakultas Hukum Universitas Brawijaya, Malang, 2013

\section{Legislations}

International Convention on The Rights of The Child

Geneva Convention 1949

Additional Protocol I 1977

\section{Internet}

Abdulla Qazi, "Biography of Ahmad Shah Massoud" www.afghan-web.com, November 18, 2008, accesed on April 5, 2019.

Council on Foreign Relations, "The US War in Afghanistan", www.cfr.org, accesed on April 10, 2019.

Detik News, "Hendak ke Pesta, 27 Warga Afghan Tewas Digempur AS", www.news. detik.com, July 7, 2008, accesed on April 25, 2019.

Nindiya Ayu Izarina, "Dampak Perang Afghanistan dan Timeline Perang Afghanistan", www.hukamnas.com, January 31, 2018, accesed on April 5, 2019.

The American Bar Association, "Enemy Combatant", www.americanbar.org, accesed on April 30, 2019.

UNICEF, "A Summary of The Rights Under The Convention on The Rights of The Child", www.unicef.org, accesed on April 30, 2019. 